\title{
Polysèmes
}

Revue d'études intertextuelles et intermédiales

$21 \mid 2019$

(Re)constructions

\section{Reconstruction and Transformation of the Museum in Wild, Wild Erie by Paul Durcan}

\section{Cathy Roche-Liger}

\section{(2) OpenEdition}

Journals

Electronic version

URL: http://journals.openedition.org/polysemes/5010

DOI: 10.4000/polysemes.5010

ISSN: 2496-4212

Publisher

SAIT

Electronic reference

Cathy Roche-Liger, «Reconstruction and Transformation of the Museum in Wild, Wild Erie by Paul Durcan », Polysèmes [Online], 21 | 2019, Online since 30 June 2019, connection on 11 June 2019. URL : http://journals.openedition.org/polysemes/5010; DOI : 10.4000/polysemes.5010

This text was automatically generated on 11 June 2019 .

Polysèmes 


\title{
Reconstruction and Transformation of the Museum in Wild, Wild Erie by Paul Durcan
}

\author{
Cathy Roche-Liger
}

1 Wild, Wild Erie, Poems Inspired by Works of Art in the Toledo Museum of Art, Ohio (henceforth WWE) is a 2016 collection of fifty ekphrastic poems published alongside fifty-five works of art from the Toledo Museum of Art. It can be considered as the third part of a trilogy-or, to better acknowledge the pictorial dimension of these volumes, of a triptych-also composed of Crazy About Women and Give Me Your Hand (1991 and 1994, henceforth CAW and GMYH). These books likewise consist of ekphrastic poems printed alongside the reproductions of the works of art which inspired them-works respectively from the National Gallery of Ireland and the National Gallery in London. ${ }^{1}$ This triptych can be defined as both the result and the embodiment of Paul Durcan's passion for art and of his pictorial aesthetics-for one of the hallmarks of his writing is intermediality, and especially the interactions of visual and verbal representations. This trilogy is also a human adventure. It is the result of the poet's encounter with a man, Dr Brian Kennedy, who is now the President, Director and CEO of the Toledo Museum of Art and who, "in the summer 1990", when he was Assistant Director of the National Gallery of Ireland, invited Durcan to "compose a book of poems out of [his] experience of the Gallery and its collection" ( $C A W, \mathrm{x})$. Durcan underlines his role in the WWE "Acknowledgements": "TWENTY-SIX YEARS AGO in Dublin, Spring 1990, I received a letter from a stranger [...] a man for whom Art is as much the Bread of Life as Poetry, Music, Prayer. The man's name was Brian Kennedy and it is he who is the only begetter of this volume entitled Wild, Wild Erie [...]" (13). Their shared passion and conception of art led to this new collection which is another intimate, highly personal response towards visual art. Durcan's ekphraseis are not mere descriptions. They are composed "out of [his] experience" of the works of art, the museum, the world, and human nature ( $C A W, \mathrm{x})$. They include the poet's personal reaction to the artworks along with his own past, his knowledge of art history, of the history of the place in which they are exhibited, or of the global context and news. Durcan connects words and images in new ways through poetry. In his CAW preface, he 
describes ekphrasis as an "intercourse", a genuine interaction between verse and image that he wishes to be "reciprocal", and hence to go both ways-from image to word and from word to image: "The challenge of art is to be inclusive and Crazy About Women, born out of a lifetime's romance with the National Gallery of Ireland, is my attempt to be so inclusive as to make the intercourse between what is painted and what is written as reciprocal as it is inevitable" (xi). After such a process, the way of looking at the pieces of art is altered too, as Brian Kennedy underlines: "Some of the paintings [...] will always be viewed with Paul Durcan's words singing in my ears. There are many truths in the lines of Crazy About Women, but one touches me particularly: Art is private relations-not public relations" (Kennedy 1996, 162). In the WWE "Foreword", Kennedy again indicates the human dimension of these new poems which "demonstrate that vision creates empathy" (12). How does the highly personal vision expressed throughout this triptych in general and WWE in particular lead to a new conception of ekphrasis, museums and art? What are the specificities of this last part of the triptych published twenty-two years after the second one (GMYH 1994)? How is the museum both reconstructed and transformed through WWE? In his introduction to the first monograph published about Durcan and in an attempt to define the poet, John McDonagh writes:

Whilst Durcan has been arguably the most politicized poet in the South of Ireland, he is also the most travelled, and his collections invariably feature his journeys [...] He is the most engaged of wanderers reveling in the different cultural experiences he encounters and finding solace in the company of strangers. [...] His poetry provides a unique geo-literary history of Ireland, as well as bringing the freshness of new horizons into view. (2)

2 This collection is Durcan's first collaboration with an American museum, his journey westward, and it provides a new "geo-literary" mythic vision of Toledo, its surroundings, and its museum of art, from an "Eastern", Irish perspective. This article will first explain how WWE can be considered as the poet's way of transcribing a fantasized experience of "westering", to use Brian W. Dippie's term, through a celebration and a pastiche or forgery of western art-or rather of a cinematic Hollywood-like version of it-, as well as his reconstruction and opening of the Toledo Museum of Art. As such-and through Durcan's conception of art that refuses categories and blurs frontiers-, this book can be considered as another illustration of one of the main features of Durcan's poetry, "Durcan's magic realism, a blend of the ordinary and the highly imaginary in which the lens through which he looks distorts and refracts" (McDonagh 124). John McDonagh also notes "a complex and often consciously unsettling use of the first person narrative voice" as being "another key marker of Durcan's poems", the "myriad 'I's" voicing a great variety of characters, including Durcan himself, in an autobiographical and nonautobiographical, fictional way: "[m]uch of the strength of his work resides in these shifting perspectives [...]. It is in the gaps and cracks in Durcan's personae, the nooks and crannies of these often fictive selves, that an elusive truth can be seen to tentatively emerge" (125-127). The present article will explore WWE by focusing on different "I"s, and mainly on the different characters who may be considered as personae for the poet. Throughout this book, the pronoun "I" can refer to Durcan himself, self-portraying himself as a museum visitor experiencing a "Contemplation"-triggered "Epiphany" (in "The Cloister Gallery", WWE, 31-33), or posing, reclining on a sculpture, enjoying art, remembering and re-experiencing his delightful visits to the Toledo Museum of Art, as a sort of new Romantic, electing to bear the Wordsworthian mantle ("I closed my eyes and smiled! O Memory!" in "The Hammock", WWE, 195-196). Generally however the first 
person is not the lyrical "I" of the poet ${ }^{3}$ but mainly refers to the many fantasied voices of characters in the different selected works of art. Yet, in many of these poems-as was already the case in CAW and GMYH-the characters' enjoyment of art can be read as voicing Durcan's own passion. This essay will first explain how the poet can be seen as "wild, wild Erie; / Mud Hen, Buckeye-of the Old Dutch Road" (WWE, 83), a cowboy transcending the notion of the frontier between words and images via ekphraseis. Then, it will focus on the poet's metaphorical West which can be seen as a dream of openness before examining how he also appears as a "Volunteer Teacher and Guide" (WWE, 89) inviting the reader to experience pure enjoyment through his recreated museum. Finally, it will conclude by showing how this new museum can be described as a cathedral built by the poet as an enchanter/"Stellar Manipulator" (WWE, 33) who expresses his faith in art by intertwining deconstructed and reconstructed Christian elements, fairy tales and nursery rhymes.

\section{Poetry as a means of exploring, appropriating and reinventing the museum space: the American museum as a reconstructed mythic metaphorical West, the poet as a new type of cowboy and ekphrasis as the way of transcending the notion of frontier}

3 Through the title Wild Wild Erie, Paul Durcan whimsically presents his book as his own adventures in a reinvented American West. The Toledo Museum of Art is located "in the Midwest" (as the poet indicates, 23), in Ohio-part of the area once known as the Northwest Territories, whence pioneers set out on the westward expansion. More precisely, it is located in Toledo's Old West End neighbourhood, in northwest Ohio, at the western end of Lake Erie (my italics). With the title and the location, the poet's trips and visits to the Toledo Museum of Art immediately resound as a double crossing: as his own westward journey from Eire to Erie. Via the homophony, it also evokes the discovery of a new, eerie place where new experience awaits. Through his poems, he explores, deconstructs and rewrites both the museum space and the myth of the Wild West. Consequently, his words can be considered not only as the transcription of his exploration of the museum, of new experience, but also as a way of expanding both the museum space and a limited conception of art, which would include frontiers.

Throughout his work, the poet repeatedly refuses categories between the different forms of art. To him, a perfect poem would include as many forms of art as possible, as he declared in a letter to Kathleen McCracken: "I see no ultimate distinction between the different 'arts' and I feel most at home in those moments, times, experiences when several or all of them come together or work together" (McCracken 18). Likewise, in his CAW preface, he writes: "An artist such as myself with the two spouses of poetry and picture-making is not looked upon favourably by the chaperones of art. [...] Art is not a prison with poetry in one cell, picture-making in another cell and so on" (xi). His three ekphrastic books (CAW, GMYH and WWE) are a way of experiencing what is only possible at the meeting point between words and image. They are his means of creating new forms of interaction between the verbal and the visual, a real exchange, or, to put it in his own words, new forms of "intercourse" (CAW, xi). In the same preface (x), the poet adds: "In 1980 I visited [...] R.B. Kitaj's 'The Artist's Eye' exhibition in the National Gallery in 
Trafalgar Square. I visited it daily for three weeks. The Kitaj show changed my attitude to art-expanded it and revolutionized it and gave me back the authority of my own eyes". This exhibition triggered the poet's freer conception of art and his ability to appropriate the museum space, as in CAW. ${ }^{4}$ WWE can be considered, after GMYH, as the latest expansion of such a conception, as his new attempt at creating a dialogue through ekphrasis. Here, on the border between words and image, exploiting its permeability and the fruitfulness of exchange, he tries to expand, blur, transgress and transcend the notion of frontier to make the artistic experience boundless.

This process is completed by a rewriting of his version of the mythic West-not of the literal West-but "its more potent form, the metaphorical West, which had [...] shaped a national self-consciousness", according to Brian W. Dippie, a historian of the American West, in his article "Drawn to the West" in which he focuses on the notion of "boundless West" through imagery and popular culture, and where he defines "Historic western American art [...] as myth in visual form" (5). He also argues that from the foreigners' perspective "it is not only the most interesting [...] but the most revealing" and he insists on the "explanatory power of frontiering" as "founding myth" (5, 7-8). It could be argued that Durcan recreates a forged idealized frontier experience, using some of the codes of the conventional narrative in some western stories to reinvent himself, ekphrasis and the museum to write them all afresh. He does so in quite a cinematic way, repeatedly alluding to "Hollywood" $(27,48,125)$ within his book, a city that Brian W. Dippie calls "America's mythic capital" (10). He plays cowboy along with the two founders of the Toledo Museum of Art, Mr and Mrs Libbey, who he turns into "Happy Cowboys" (116) in the ekphrasis of a photograph representing them riding camels in Egypt. Moreover, the Wild West myth crops up regularly throughout WWE with the repetition, in the same poem, of the adjective "wild" ("the wild, wild merry-making", 118); with further reference to "Wild, Wild Erie" as in "Spiegel (Mirror), 2010" (185-188); or with the repeated references to Maumee(s) (both to the place-the suburb next to Toledo-and to the Native American tribe, $30,69,89,187)$. In the same way that he imagines the institution's founder Mrs Libbey riding to the museum on the back of a camel (117), the poet invites the readers to become new types of "Happy Cowboys", exploring art merrily and differently, just as he did.

6 Visiting the museum and reconstructing it through words and image in WWE, Durcan becomes a new type of cowboy, an "[explorer or visitor] seeking something that cannot be found elsewhere"; he becomes "a man who has established a sort of symbiosis", not "with nature", as in the original western myth, but with art (to use Eric Hobsbawm's description of the "main essence" of the two types of white protagonists of "the original wild west epic"). ${ }^{5}$

7 The figure of the horseman-hero first indirectly appears as soon as we open the book through the reproduction, on the left page facing the title, of A Dutch Road by Anton Mauve [fig. 1]: a nineteenth-century Dutch oil painting of a road with a man riding a horse and bringing two extra horses along with him. 


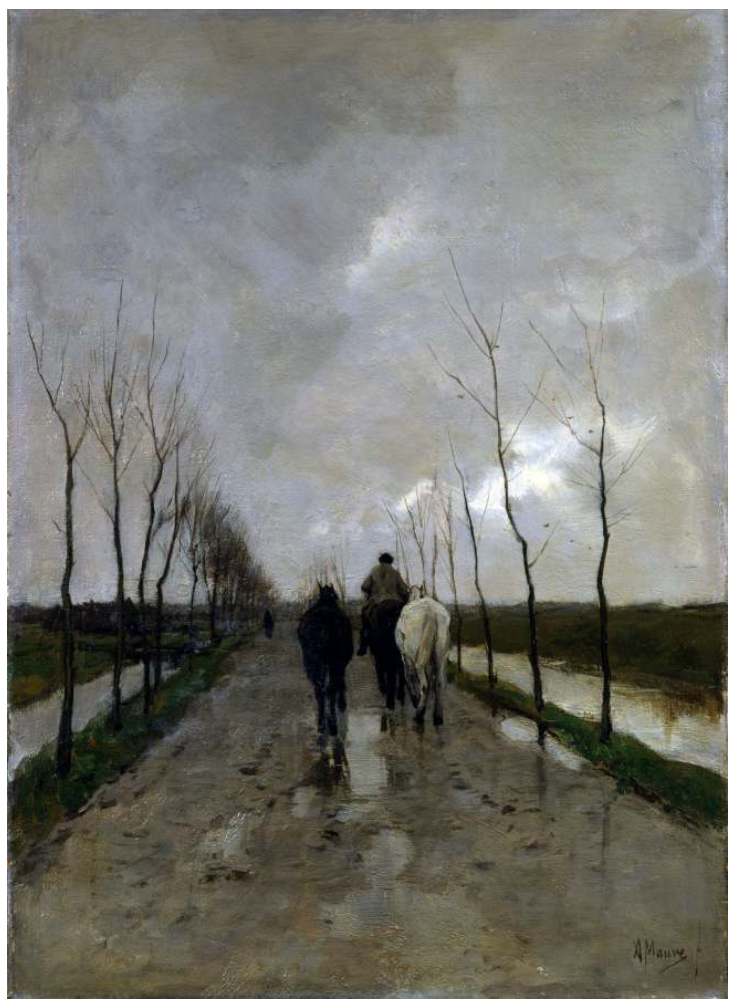

Fig. 1: Anton Mauve, A Dutch Road, oil on canvas, about 1880, 50.5×36.8 cm, Toledo Museum of Art. (C) Wikimedia commons.

According to the presentation of the painting on the website: "Mauve and his contemporaries tried to depict nature and the 'simple life' of rural communities that was beginning to be supplanted by the Industrial Revolution and rapid urbanization. Mauve's use of grays and browns gives this painting an overall feeling of a dreary, rainy day as the people are heading to or from a day's honest work". Durcan decontextualizes this vision and turns it into an invitation for the reader to become one of the new "Happy Cowboys" (116), to saddle up and ride out, to follow the poet's lead and explore the museum differently, to let their minds roam freely while enjoying the works of art. When the figure of the horseman or new cowboy appears again on page 82 and 83 with the same reproduction of Mauve's work facing the poem entitled "A Dutch Road, about 1880", the frontiers separating countries are blurred as this Dutch Road is relocated in contemporary Ohio, in a time of "brand new iPhones". This road is described as "The north road to Erie" and "Forever headed to the North Pole Fair". It becomes universal, a symbol of life itself. The "all-grey winter's day" is transcended and the ekphrasis of the painting appears as a humorous meditation on life, unfulfilled expectations, endurance, and hope through a rewriting of the Dubliners' song "Love is Pleasing" (1964)-which is about an unfulfilling romance and immigration to the USA $-{ }^{6}$ of North Pole fantasies, and of American western:

That life is a Dutch Road in Ohio -

The north road to Erie - [...]

Savouring the death of all,

Yet knowing in your soul

Prophetically

That Spring will come round again [...]

"What cannot be cured love

Has to be endured love 
Forever headed to the North Pole Fair";

I am wild wild Erie;

Mud Hen, Buckeye - of the Old Dutch $\operatorname{Road}^{7}$ (83)

Mud Hen, which is another term for the American coot, refers to the local Toledo baseball team and also conveys an impression of rural America. The buckeye is the state tree of Ohio. It also refers to the pioneers on the Ohio frontier because it was the Ohian military hero William Henry Harrison's nickname. The fantasied voice of the horseman-which can be considered as a persona for the poet-a "farmer" calling himself "wild, wild Erie; / Mud Hen, Buckeye", firmly inscribes himself as one of the great, central figures in Durcan's reconstructed myth of the frontier.

\section{Writing as a means of opening the museum space and creating interactions: rewritten Bible, reversed wanted posters and Wild Wild Erie as a dream of openness}

This myth is further deconstructed and transformed in "The Flight Into Egypt, about 1540-45" (19-21), an ekphrasis of Jacopo Bassano's work [Fig. 2]. The poet does so when he turns the Biblical episode into a western scene where Mary and Joseph-called "Old Joe"are "refugees", "Illegal immigrants", "being always on-the-run, always being WANTED". With its capital letters, the word "WANTED" visually reconstitutes the eponymous posters from western films. Yet, opposing the "family of travellers" to "respectable, uppermiddle, middle-class" people (19), he transforms the Holy couple and, by association, all the refugees of our modern world, into embodiments of "the Future of Cool" (21). In so doing, he comments on the current western world and its closing of frontiers. He creates another version of the Wild West mythology, the one Brian W. Dippie conceptualizes as "a geography of hope and dreams" $(23,26)$, one that conveys the "dreams of white pioneers who hoped for better lives in a western promised land", while reminding us that "dreamers come in all colors and from all cultures" (21). Through the contrast between Now and Then, and the projection into the Future, Durcan triggers humour and writes both a strong contemporary comment and a vibrant homage to refugees and outcasts. He creates a "dialectical image" which fully exploits the "paradoxical fruitfulness of anachronism" to use Georges Didi-Huberman's concept. ${ }^{8}$ With this "dialectical image" and the repetition of the adverb "always", he makes his recreated version of the myth eternal, out of time. In CAW, in "The Meeting On The Turret Stairs" (93), the poet creates a similar effect when he turns the watercolour into a mythopoetic love encounter, eternally re-experienced through time, by anachronistically rewriting details and via his use of the adverb "always" as well as his repetition of "the same". 


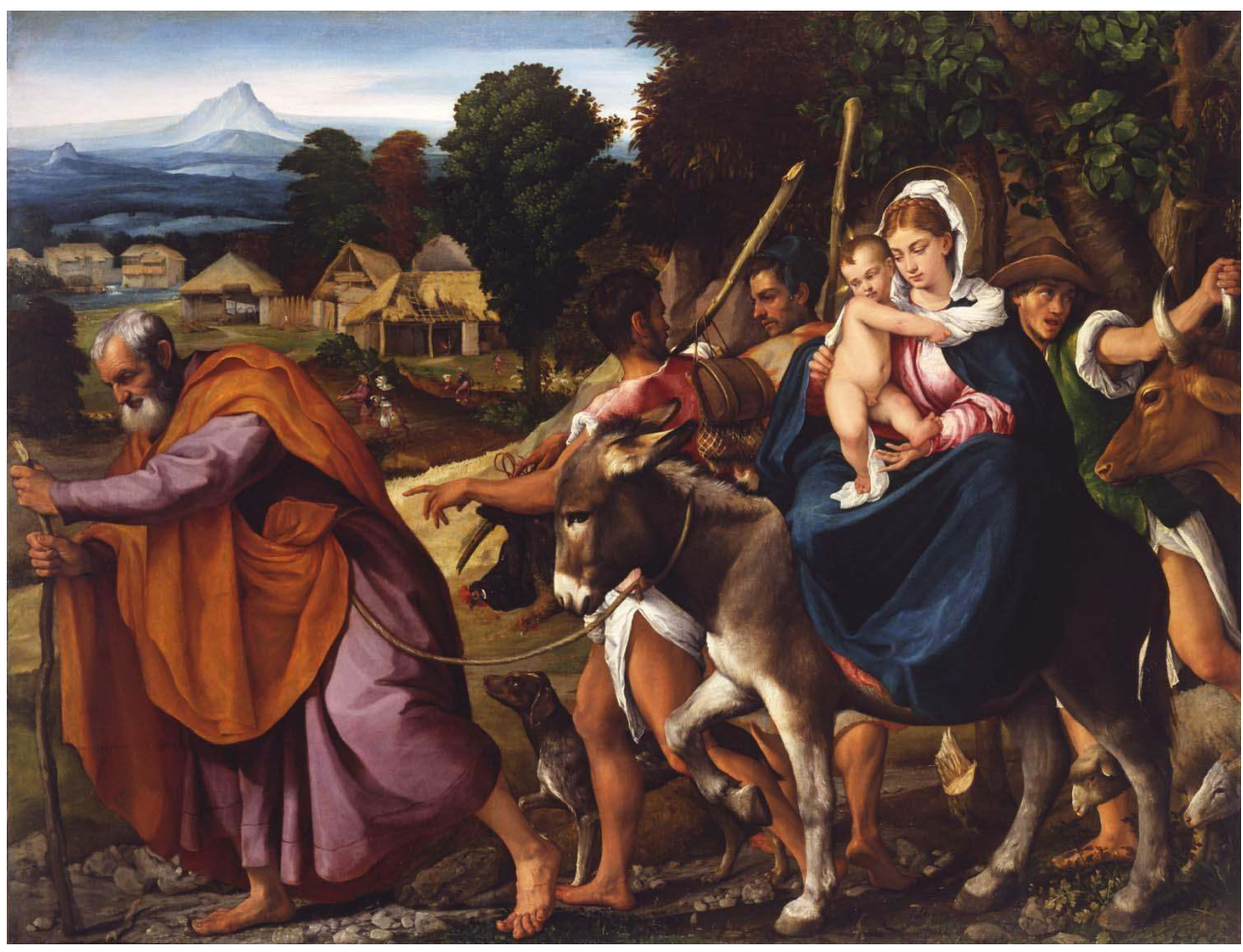

Fig. 2: Jacopo Bassano (Jacopo dal Ponte), The Flight into Egypt, 1540-1545, oil on canvas, $157.5 \times 203.2 \mathrm{~cm}$, Toledo Museum of Art.

(c)Toledo Museum of Art.

Durcan rejects boundaries, even temporal ones, and frequently uses anachronism by juxtaposing or associating elements from different time frames throughout his work. He does so again in WWE, when he transforms the naked body of the infant Jesus into that of "a future gold medallist" wearing a "Gymboree outlet" while at the same time minutely and humoristically describing it through the fantasized voice of Jesus himself in "The Adoration of the Child, about 1495-1500" (17):

$\mathrm{Ma}$, forgive me, but I am actually not in the raw:

Grandma got me a body-hugging outfit

In a Gymboree outlet in Westlake, Ohio:

It's four-in-one: jump-suit; romper; body-suit; and one-piece.

The four-in-one shows off my body-and-soul to best advantage;

All my wrinkles, all my creases, all my puffiness crumpled-rumpled;

All my fatty, roundy body parts in finest flower;

My chubby bell-push compact penis; ditto my belly-button;

What a chubby little champ I am for a future gold medallist! (17) 


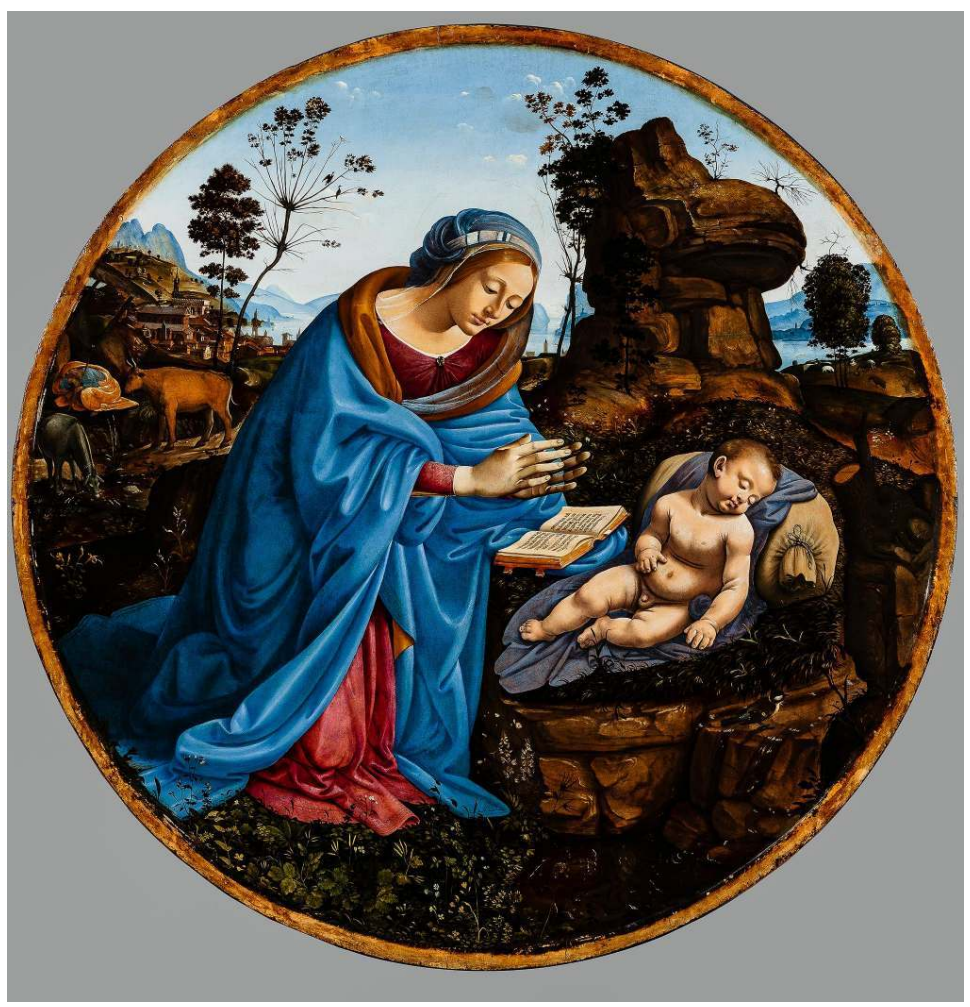

FIg. 3: PIERO DI COSIMO, THE ADORATION OF THE CHILD, ABOUT 1495-1500, OIL ON PANEL, DIAMETER $160 \mathrm{CM}$, TOLEDO MUSEUM OF ART.

(C)Toledo Museum of Art.

Similarly, the "Man in a Fur-Lined Coat, about 1655-60" becomes "a seventeenth-century Dutch Hollywood movie-star" (27). In CAW, GMYH and WWE, Durcan takes the works of art out of their physical frame on the wall, which is generally not reproduced on the page. So doing, he also takes them out of their time frame and of their permanence to make them move, evolve, and interact with the current real and fictive world.

Through his juxtaposition and transformation, he mixes what is traditionally labelled as high and popular cultures. In WWE, the title itself with the repetition of "wild" can be seen as both indicating anachronism and pointing to popular culture with the reference not to the original Wild West epic, but to the title of an American television series that ran on the CBS television network in the 1960s. The anachronistic dimension is doubly reinforced through this reference to Wild Wild West, since the series resorts to a number of fantasy elements, such as technologically advanced devices, in a nineteenth-century time frame.

Thus, WWE can be viewed as a reconstruction through the double rewriting of the Bible and the American myth. Through intratextual effect, this poem is also a partial reconstruction of other ekphraseis by Durcan, involving the reworking of Christian imagery. This poem can be considered as a construction enabling him to condense image and temporalities (including that of the myth), by superimposing, juxtaposing or intertwining them. Indeed, this text first echoes the first poem in WWE, "The Adoration of the Child", with the phrase "refugees on the run!" (18). This element also echoes "The Virgin and Child", an ekphrasis of a sculpture in CAW where Mary and Jesus are defined as "Outcasts in terracotta; refugees in clay" (9). Moreover, the Virgin "in her frisbee halo" 
(21) also echoes another ekphrasis in CAW: "The Holy Family With St John", and more precisely the nominal group "frisby halos" (11). Finally, his description of the Virgin as "a queen", "the epitome of prettiness, of dignity, of wholesomeness; / Her red hair tied up in a braid across her head" (21) also reverberates with all his previous descriptions of the Virgin where he emphasized her beauty, by even eroticizing her sometimes, or where the poet intertwined his own mother's beauty, or incestuously women's beauty in general, with that of the Virgin, the archetypal mother. Throughout The Days of Surprise for example, the book which was published in 2015 when he was writing WWE, the Virgin appears as a (red-haired) beauty. ${ }^{10}$

The poet rewrites and combines different myths, stories, and imageries, refusing to separate them, but associating them to make them more powerful. He, for instance, also refers to the myth of the American dream to better rewrite it:

Huckleberry Finn sez it's fine so it must be fine!

Sez it's all part of the American Dream -

What can he mean?

That we're all cherokee and Maumee

If we could only see it? (69)

Twain's book is a celebration of the American dream as freedom through different dreams of prosperity and happiness but Durcan turns it into a questioning, one that would point towards universal brotherhood, acceptance and celebration of the Native Americans rather than individualistic fulfilment and space conquest.

Durcan does not believe in limits neatly separating forms of art, myths, geographic areas, men and women, humans and animals, or any categorisations. In "Still Life with Grapes, Chestnuts, Melons, And a Marble Cube, about 1800-10" for instance, the elements composing the still life are turned into a naked woman (41); in "Under the Birches, Evening", the "mare [...] could be the Mother of God" and the "birch-tree / Have formed a guard of honour" (52-53); or in "Cathedral woods, Monhegan Island, 1911", "trees are the Persons / Trees really are" (111). He builds up a world where everything is in a state of perpetual transformation and transmutation.

Throughout WWE and his work in general, he unites and combines different forms of art: poetry, painting, sculpture, photography, architecture, cinema or music. In addition, both in CAW and in WWE, loosely quoting Walter Pater, he states that "All art aspires to the condition of music" (respectively in "Portrait of a Man Aged Twenty-Eight" after Georg Pencz [CAW, 24], and in "Rainy Day, Boston, 1885" [WWE, 94]). ${ }^{11}$ He thus situates his work within a musical, rhythmic aesthetic in the continuity of that of Walter Pater. He also includes direct music references at the end of "Rainy Day, Boston, 1885" (89-94):

I want you all to exit the Toledo Museum of Art

Humming or whistling Elgar's Hassam Variation on Child(e).

Ciao! Have a nice trip around Lake Erie. (94)

These lines convey both the end of boundaries separating the arts and the poet's wish for this new experience to continue expanding and not to stop when one closes the book or leaves the museum space. The same poem opens with the lines:

So folks, what we're looking at now-[...]

One of the most under-rated masterpieces, not only

of Nineteenth-Century North America American Art

But of Nineteenth-Century Art anywhere in the world

(The World including the Indigenous-

From the Ganges to the Volga to the Bulloo to the Maumee)-(89) 
obal, all-encompassing vision, which rejects a eurocentric point of view, echoes his opening of the museum space. This opening is not limited to the outside of the museum or to its nearby surroundings (like "Monroe" Avenue and "Collingwood" Boulevard, 91). Reading and turning the pages, the readers discover the works of art and the museum galleries or "museum store" (23), and they travel as well. They go around Toledo, to "Lake Erie" (91, 163 or 183) or to "Ashtabula, Ohio" (19). From the Toledo Museum of Art, they also go to other museums such as "the Museum of the Louvre" $(127,147)$ or "The National Gallery in Trafalgar Square" (68). They go all around the world (from "Westlake, Ohio" to Ireland, via "Damascus", 17-18; "In Dublin Bay [...] All the way from Japan", 151; from "Gare du Nord", Paris to "Auvers-sur-Oise", 73; or to "Cairo", 115); to even find themselves admiring "The Pleiades and The Plough and Orion and Cassiopeia- / And the planet Jupiter" (33). This list of place names also reverberates throughout Durcan's work as, ever since his childhood, they have been "part of the magic of life", "poetry in themselves, mainly English names of course, but also actually names in other languages, names in other countries" (Durcan, private interview). It can be considered as his latest expansion of his own partial reconstruction of the Irish tradition of the dindsenchas or "lore of places", through which the etymology of place names as well as events and characters associated with places has been related since early Irish literature-an enlarged reconstruction through the dimension of globalization. still life by the American painter born in Ireland, William Harnett, or an oil by Jack B. Yeats, an artist he greatly admires), through references to the Yeats family-Jack's brother William B. (196) and his father John B. (113), to James Joyce (141), to Oscar Wilde $(134,151)$ or the Irish leader Michael Collins $(151),{ }^{12}$ or by quoting the music band the Dubliners (83), Seamus Heaney $(47,130)$ or his mentor, the poet Patrick Kavanagh (196); or through reference to his native land, for instance naming "the Beautiful Town of Westport" (18), "Westport, Ireland" (195)-the place from which his family hailsrespectively in "The Adoration of the Child" and in "The Hammock", that is to say in the first and the last poem in WWE. This adds a framing effect. Westport appears as the place from which he started his journey and to which he will return. ${ }^{13}$ But in "The Hammock", he also refers to himself as a "citizen of the Union", compares himself to "any selfrespecting, horizontal hobo", and defines himself as someone who has travelled the world, as a citizen of the world with the following lines:

From Paris, France to Paris, Texas;

From Westport, Ireland to Invercargill, New Zealand;

From Alice Springs to Kyoto To Barcelona to Novosibirsk

Durcan also creates a linguistic reconstructed patchwork, which conveys humour and a sense of globality and opening. In so doing, he shifts his own personal voice to partly Americanize it. The poet seems to be straddling the border between seriousness and caricature since he includes American places, phrases and words in the poems as well as elements non-Americans might associate with the idea of what America is and what Americans would say, such as: "Howdee" (177), "dude" (23), "guys [and] dolls" (119); slang and informal transcription of speech such as "champ" (17), "kinda" (27), "I dunno (173)"; his many uses of the word cool (either as an adjective or a verb) as in "Baby sis, cool it" (119) or "Cos you're cool" (29); his use of capital letters as in "I LOVE" (29) or "WOW" (119); the occurrence of " $180 \%$ " (90). He does so while at the same time retaining his own variety of Irish English (i.e. "colour”, 17, “centre”, 47, "storey”, 85 or "he used cry", 145 
instead of "he used to cry"). He both uses "Autumn" (42) and "Fall" in the phrase "The Light of the Fall" (70) to play on the double meaning of "Fall" the biblical connotation of which is emphasized by the fact that it follows the line "We're all innocent if we only knew it". ${ }^{14}$ The American coloration of his language is a tribute to Ohio and its museum, a way of including the fact that the works of art are exhibited there. It is as if these works of art had been transformed by their American surroundings and interacted with them over the years. This tribute is extended and reinforced by the many references throughout the collection to local elements and American culture in general: "Huckleberry Finn" (69), "Henry Ford" and "An A-Model Ford" (133), "Holiday Inn" (30), "Hollywood" $(48,125)$ or "Casinos" $(48,125)$. The sense of a reconstructed linguistic patchwork is further conveyed by the fact that he also includes French phrases such as " L'Audace! Et encore de l'Audace! Et toujours de l'Audace!" (113), phrases mixing languages (such as "Mon petit, it was absolument very heaven in 1911 to be a young woman à Paris", 109) or segments juxtaposing words in different languages ("Thankee, high-fives, danke, spasíba, shukran, tashakor, merci!", 45). His apparent love for the word "Maumee"whose sonorities he plays with in "Silver Erie" ("My Mom named me Maumee. / Erie: / I am your Maumee", 187)-encapsulates this multi-lingual aspect, as the world "Maumee" is the Americanized version of the name of an Indian tribe through another Indian language: the anglicized spelling of the Ottawa or Odawa name for the Miami tribe, Maamii. The internationalization of his language and of his references emphasize Durcan's global and whimsical vision as well as his desire to break down boundaries.

The poet intertwines what is unique and extraordinary with the universal and "That most sublime subject-matter of all-the ordinary" (98). He does not describe the museum as a closed environment but as a source of unbounded pleasure and enjoyment with a tendency towards extension. It is perceived as an indoor and outdoor space, which has no fixed, delineated end. In "The Hammock", a poem inspired by a sculpture by Pinaree Sanpitak (Blown glass and steel, 2014), the museum is depicted as a grand building with "scintillating flight of steps" and "Ionic Columns", but also as "an urban park" with sculptures. Durcan removes the distance that is supposed to separate a viewer from a work of art and depicts himself snoozing in it. He blurs the frontier between the mundane world and the museum experience. Consequently, he describes himself lying in the hammock while enjoying the view of the cars passing by as if they were works of art, in motion, dancing:

Here I am reposing like a stag tilting in full flight,

Swaying in the breeze under oak tree and maple, [...]

In urban parkland, watching the auto-traffic-

Semis, arctics, flatbacks, limos, taxis, coaches, buses, tankers, Buicks, police cars

And Cadillacs, Cadillacs, and more Cadillacs

of every hue and colour in the palette-

That a choreographed procession to amuse my reclining torso!

And across Monroe Street the façade of the Toledo Museum of Art-

That scintillating flight of steps, the Ionic Columns,

Alexander Calder's scarlet Stegosaurus stalking the redbrick terrace. [...] (196)

Thus, in WWE, from the circular shape of the first painting-a tondo- (see fig. 3 ) to the semi-circle of the Hammock-the last work of art reproduced-the general movement is that of an opening. Nonetheless, Durcan not only blurs boundaries, plays with their permeability, and tries to dispense with them. He also plays with and uses frames in order to guide the reader. The poet wants the reader to share his enjoyment and, in turn, 
experience an intense pleasure both while reading the poems and while visiting museums anew.

\section{Wild Wild Erie, or the invitation to be passionate and experience intense pleasure: the Poet as a "Volunteer Teacher and Guide" and ekphrasis as a form of "intercourse" leading to rapture}

In WWE, Durcan extends his previous invitations (CAW, GMYH) to the reader to take his "hand" and follow him through museums, to discover them anew, to learn how to freely and truly enjoy works of art, to be "crazy about" them, "wild" about art. This book can be seen as his address to all his readers as well as to all the "tender-hearted curator[s], gallery-tripper[s], art nerd[s]" to come and visit and enjoy art differently (to use Durcan's phrase in "Brook by Moonlight, before 1891", WWE 105). In WWE, he describes himself visiting, enjoying the museum, but also subsequently remembering the experience of enjoying it so as to revel in it again as in "The Cloister Gallery" and "The Hammock" (31-33, 195-196) where the "I" can clearly be identified as being the poet. He also gives voice to other characters' passion for art to better convey his own.

In "Rainy Day, Boston, 1885" (89) [fig. 4] the pronoun "I" refers to "Albie Scattini, [...] your Volunteer Teacher and Guide", one of the numerous fantasied voices that can be heard throughout WWE, a voice that can be considered as a persona of the poet. The ekphrastic description through the guide's invented direct speech is a funny tribute, a reconstruction mixing what could be the documented words of an art historian with an eroticized, whimsical description echoing the poet's pleasure experienced while observing this work of art:

"Rainy Day, Boston", was inspired

By the young painter's recent brief sojourn in Paris;

Magisterially, he has taken his cue

From Gustave Caillebotte's "Paris Street, Rainy Day"

A French masterwork painted in 1877 when Childe Hassam

Was barely seventeen years old-

(Happily-in the way of these serendipities-

The Caillebotte is now our neighbour in the Chicago Art Institute.)

Caillebotte's painting is an erotic dance of umbrella spokes

At the junction of five streets [...]

By reducing his street-scape to three [...]

He has purified Caillebotte's eroticism

By making his own depiction an homage to

And Celebration of Wetness-

$180 \%$ wetness.

Look! Just even by my momentary glancing at the painting

I'm soaked by Hassam's "Wetness"-all that clammy wetness.

Standing here in the dry (!) gallery of the Toledo Museum of Art

I feel compelled to hitch up my pants ever so slightly

And save my Italian shoes from getting TOO wet (90-91) 


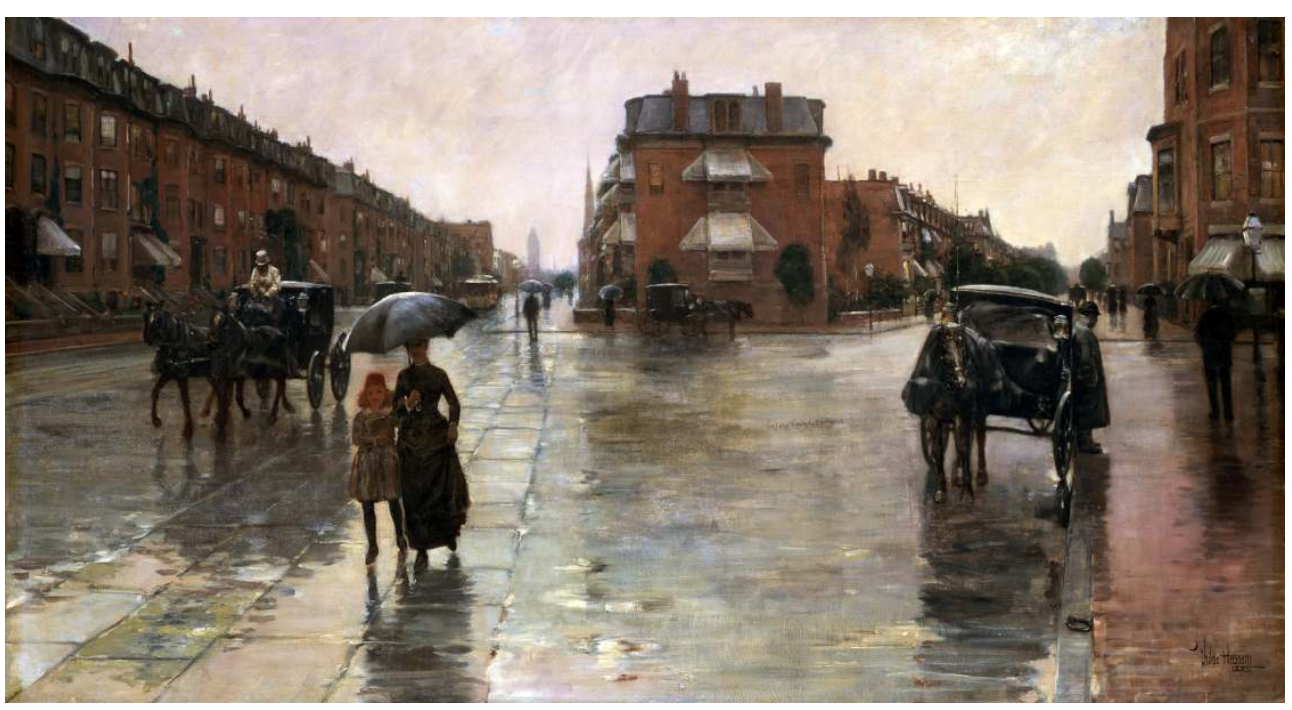

Fig. 4: Childe Hassam, Rainy Day in Boston, 1885, oil on canvas, $66.3 \times 122 \mathrm{~cm}$, Toledo Museum of Art. (C) Wikimedia commons

Real and fanciful art history critiques are mixed here. There is also a real interaction between the viewer and the work of art, an interaction partly voiced in a way which echoes the comment in the first poem: "(Visitors, please stand back or you might get splashed and wet)" (17). There is a form of delight to be shared. Brian Kennedy, in his "Foreword" to WWE writes: "PAUL DURCAN will tell you that nothing gives him greater satisfaction as a poet than bathing in the pure enjoyment he experiences with works of visual art" (11). This enjoyment is repeatedly transcribed within his direct or more indirect descriptions. It is also voiced through the fantasied words of painters such as Paul Cadmus or Henri Matisse, respectively transcribed by their models in Durcan's poems: "OO such nipples, such armpits, such biceps, / Such fingers, such eyebrows, such elbows, such ribs...' you mumble"; '“Your BODY LANGUAGE' he used cry, 'your BODY LANGUAGE"' (145).

The aim of an artist is to explore new territories, to extend boundaries and to break through new frontiers, and that is what the poet does here, by playing once again with frames and conventions. Throughout WWE, nothing is fixed or neatly framed. Just as he did in $C A W$ and GMYH, except for two paintings and a mosaic box, he de-frames the works of art before reproducing them, as if he wanted to abolish any possible frontier that would create a limit to his imagination or a distance between him or the reader and the works of art. In WWE, in "Still Life with Grapes, Chestnuts, Melons, And a Marble Cube, about 1800-10" (41-43), the intense form of enjoyment and wish to create a real "intercourse" with the artwork which can be read in "Rainy Day, Boston, 1885" (89-94) reappears both by his turning of the still life into a strip-tease scene and in his way of playing with frames:

Unzipping her thigh-high black leather boots

She threw down her mink greatcoat

On the floor of my library [...]

Letting slip her black jeans and her turquoise blouse,

she took my hands in hers

Silently saying: "These are yours"-

Three bunches of small red grapes,

Two enormous golden-green super-ripe melons,

Three spiky chestnut pods [....] (41) 
When the Toledo Art Museum Gallery Guard

Is not looking I pluck

The white marble cube from the wall of my soul,

Place it on my scorching-hot fevered forehead,

Hold it down long as I dare

Before placing it back into its frame

Back into its own illuminating, illuminated night-life. [...]

For only a Still Life is never still! (43)

Durcan's way of describing details is a sign of the intense pleasure he feels in front of a painting, in the detailed observation, and again in the process of writing about it. It is also a means of conveying his personal perception of the work of art by his reframing of it through details. The process of eroticizing the paintings through details and his way of playing with frames are in the direct continuity of what he does throughout CAW, GMYH or his work in general (see Roche-Liger 68-83). Furthermore, here as in CAW and GMYH, he also underlines the power of the frame. Each time the frame remains, it becomes important to the poem as in the first one, where Piero di Cosimo's tondo's round form (see fig. 3) reverberates within the text through the motive of the round, from Jesus' "belly button" to "the turning world, Round and Round", "the cosmos" which "after all, is spherical" (17-18), from the echo and partial reconstruction of the mother and baby's game and rhyme "Round and round the garden, like a teddy bear", to the partial visual reconstruction of an illuminated book with the reproduction of the tondo standing for the letter "O", and to the round movement within the visual aspect of the text itself which seems to be undulating via the alternate long and short lines.

Durcan not only blurs limits and frontiers and tries to extend them. He is also extremely familiar with them and knows how to use them too in order to guide the reader. He is the "Volunteer Teacher and Guide" (WWE, 89) who makes the reader focus on specific details, for instance when he writes: "Look closely at his signature: note the crescent moon!" (89). The poet also re-frames the reader's vision and influences his perception by selecting works of art, by reproducing them in a carefully selected way, by reproducing some details of some works of art as well as the whole reproductions. The reproductions are mainly placed on the left page opposite the poems. But there are five other configurations. There is only one occurrence of the opposite spatial organisation with one poem on the left page and the reproduction on the right page. There are poems framing the reproductions which are reproduced in the middle; or poems framed by the whole reproduction and a detail from it; or an oscillation between the reproduction, the poem, a detail and the end of the poem. Each time, the ways the words and images are spatially laid-out are meaningful. For instance, in "Antonin Proust, 1880", the reproduction only appears in the middle of the poem, after the line "Signals to us Proust's secret", as if this secret was whimsically revealed to the reader only when he turns the page and discovers the painting. By replicating twice some paintings to also place them opposite the title, the contents, the foreword, or the checklist, the poet puts them in another perspective and creates another meaning.

The impression of reading a new sort of guide is also conveyed by the visual aspect of the book itself. Durcan plays with labels and labelling. Under each reproduced work of art, the author's name can be read. The titles of the poems are the titles of the works of art, and their subtitles are their dates of creation. Just as in CAW and GMYH, they also appear in chronological order. Such precisions led Brian Kennedy to refer to the poet as "a traditional art curator" ( $C A W, \mathrm{ix})$. These elements give the reader the impression of 
looking at new, pieces of description reminiscent of the labels found on museum walls. The poems are new types of extended frames. To use Jacques Derrida's concept (19-168), each of them can then be considered as a "parergon", that is to say as both part of and foreign to the art piece, as something that frames it, delineates it, archives it, and comments on it. Furthermore, the fact that, at the end of the book, there is a "checklist of works of art" which includes small reproductions of all the reproduced art pieces, with their authors' names, titles, dates of creation, materials, dimensions, and details of their purchase is reminiscent of archives, museum catalogues and guides.

WWE can be more specifically conceived both as a partial reconstruction and as an alternative or extension to Paula Reich's Toledo Museum of Art, Map \& Guide, in the sense that the reader finds echoes of the Guide's "A Closer Look" sections in the inclusion of details and in their descriptions. One of these details, included in "La Salle Clarac, 1922" (130), a poem dedicated to Paula Reich (127), is the detail used for the cover of Reich's guide (from a 1922 painting by Vuillard, see fig. 5). In addition, Reich guided the poet throughout his visits. In his "Acknowledgements" (13), Durcan describes her as his "inhouse-in-museum!-editor, guide, mentor, shepherd, manager" and refers to his book as theirs ("[she] inspired as well as enabled me to compose our book").

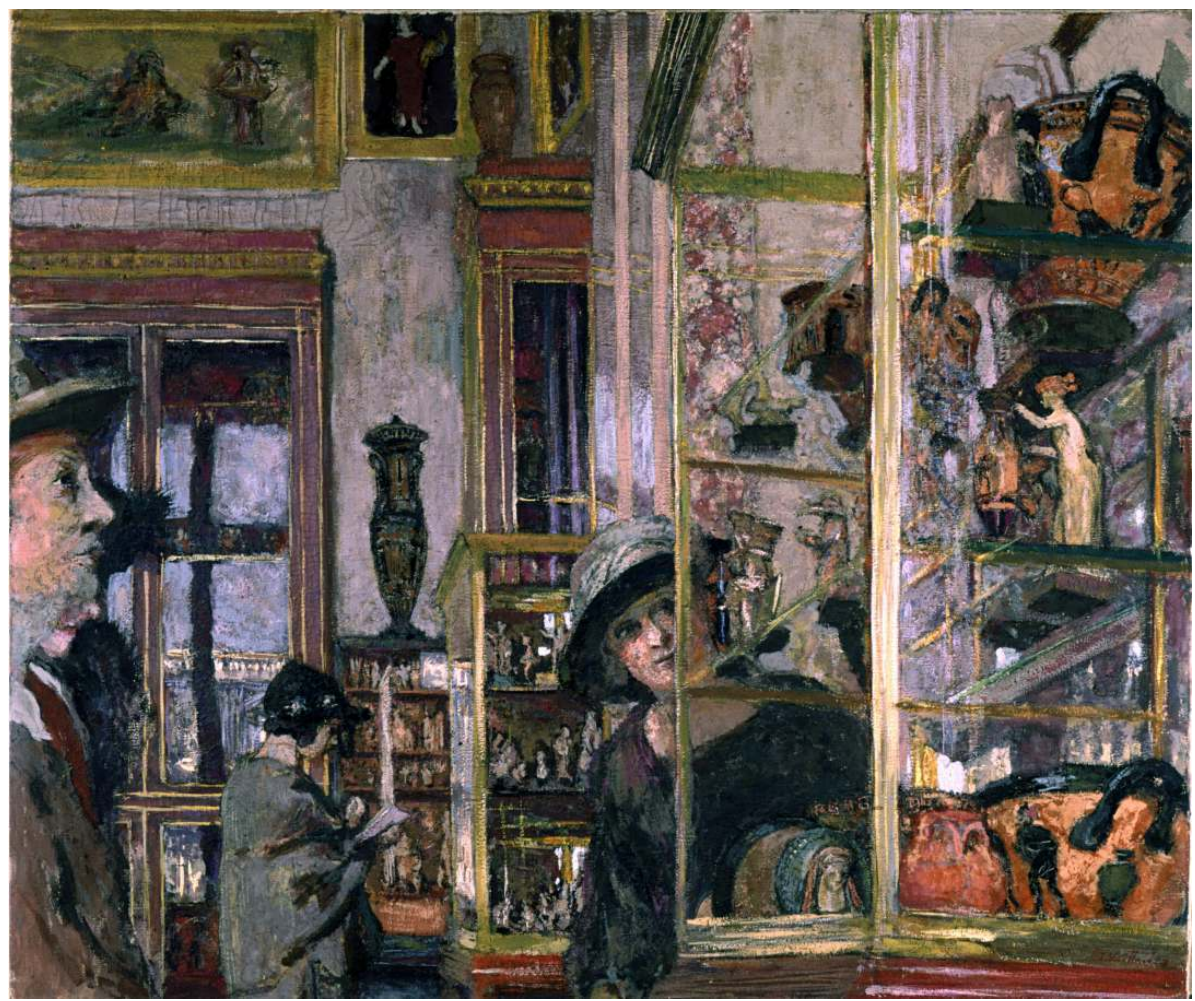

Fig. 5: Édouard Vuillard, La Salle Clarac, 1922, oil with distemper on canvas, $98.1 \times 115.9 \mathrm{~cm}$, Toledo Museum of Art.

(c) Wikimedia Commons.

This collection is both scholarly and highly documented. Durcan repeatedly visited the galleries and museums, alone or in the company of the curators or of other museum staff members, taking notes while also observing and listening to the visitors. ${ }^{15} \mathrm{He}$ also read many books about art history, including some that are not directly related to the museum he was writing about, such as Prodigal Father by William M. Murphy, a book about John B. Yeats that he quotes in "Cathedral Woods, Monhegan Island, 1911" (113: "John Butler Yeats-'The Prodigal Father' / William Michael Murphy, the scholar, named him-"). 
Consequently, WWE can be considered as his construction or device to guide the reader, to bring him to look at the works of art in a certain way before giving him freedom, before giving him "back the authority of [his] own eye" (CAW, $\mathrm{x})$ just as the Kitaj show did for Durcan. It is an initiatory experience which is only made possible through the poet's combined passion and erudition. It celebrates the power of the eye, by showing how contemplation can lead to delight, rapture, or even ecstasy or "Epiphany" (31).

"I am eye-balling you!" (WWE, 67) the woman in Durcan's “London Visitors" says, hence suggesting how the act of watching something can be bold, a form of challenge and a source of pleasure. Paula Reich in her critique of the painting in the Toledo Museum of Art guide refers to her "bold gaze" as "the "Free Eye", a silent invitation that Durcan transforms to make it his own:

Locking eyes with someone on the steps, or perhaps the viewer of the painting, her forthright gaze breaches feminine propriety. A popular book on decorum warned, "The free eye is a marked characteristic of the libertine, and all modest women should turn persistently from its roving and unlicensed glances." A silent conversation seems to take place [...]. The abandoned cigar projecting over the step suggests this unseen, "libertine" presence. The woman elegantly holds her closed umbrella to point casually toward Trafalgar square. Her bold gaze and unmistakable gesture may invite her unseen admirer to meet her in the square. (38)

Just as the Woman in James Tissot's London Visitors (fig. 6) indicates with her umbrella the way towards another sort of pleasure, far more fulfilling than a mere tourist consumerism, Durcan invites the reader to erotically, passionately "[eye-ball]" the artpieces and to understand that, as he points out in his acknowledgements, "Art is as much the Bread of Life as Poetry, Music, Prayer" (WWE, 13).

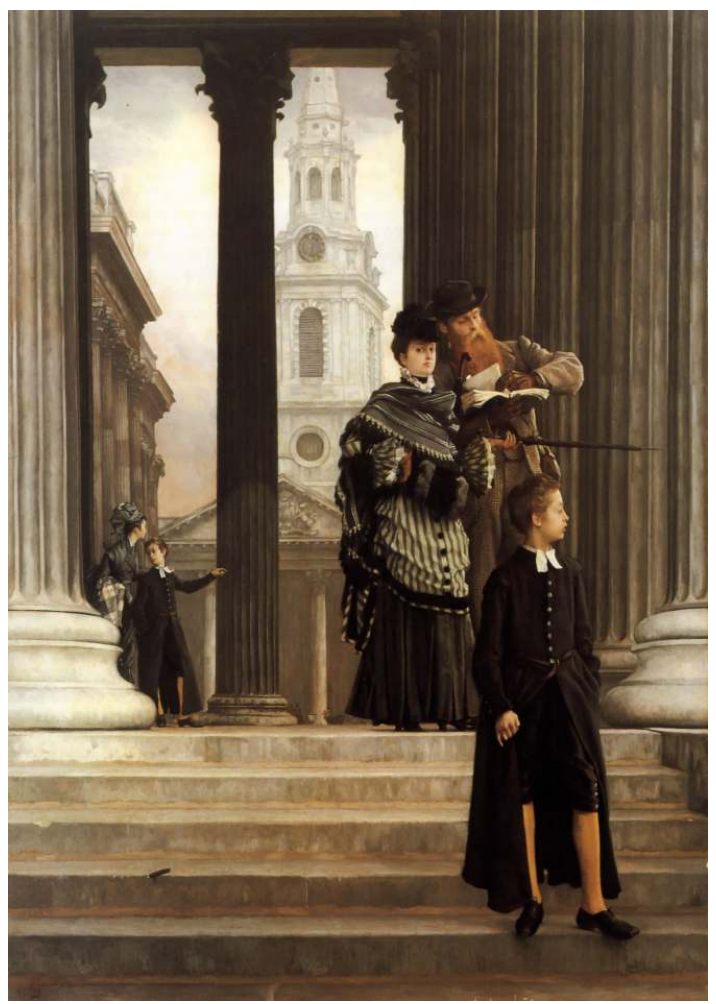

James Tissot, London Visitors, about 1874, oil on canvas, 160x114.2 cm, Toledo Museum of Art. (c) Wikimedia Commons. 


\section{Conclusion: "another liturgical season of contemplation": the Poet as a Story-teller, an Enchanter, a "Stellar Manipulator" and Wild Wild Erie as an enlarged Poet's Corner, a Constructed Hallowed Enchanted Space both Museum and Fairy Tale Cathedral Within Which he Expresses His Faith in Art}

In CAW, GMYH and WWE, Durcan blurs frontiers and plays with frames. He de-frames the artworks to better reframe them with his "experience", his perceptions, his fantasies. He experienced intense pleasure while visiting the museums, contemplating the works of art, imagining the stories they could tell. He prolonged this pleasure by writing his ekphraseis and invites the reader to enjoy both the works and his words and to extend the experience, to imagine other stories, to look at the pictures anew. Kennedy refers to $C A W$, GMYH and WWE as "a trinity of books of insightful, creative storytelling" (WWE, 11), and indeed, each poem is a new tale, a new journey, which leads the reader towards "another liturgical season of contemplation", to put it in the poet's words from "Dancer Resting, 1940" (WWE, 147). Through it he re-expresses and reaffirms his faith in art. In 1975, in "They Say the Butterfly is the Hardest Stroke" (O Westport, 48), the poet expressed this faith through the celebration of three writers he admires:

I have not "met" God, I have not "read"

David Gascoyne, James Joyce, or Patrick Kavanagh:

I believe in them.

As Edna Longley points out in her introduction to The Selected Paul Durcan, "Durcan is visionary, first of all, in his faith. This faith extends to literature itself, as when he salutes a significant Trinity of writers" (xi). Here, this faith extends to art in general.

Throughout WWE, Durcan re-writes art history. He re-invents it, mixing it with deconstructed and reconstructed Biblical scenes, Wild West epic, or fairy tales and nursery rhymes such as Snow White in "Still Life with Grapes, Chestnuts, Melons, and a Marble Cube, About 1800-10" (42) and "Spiegel (Mirror), 2010" (184), ${ }_{16}^{16}$ or "Twinkle, Twinkle Little Star" both in "The Cloister Gallery" (33) and in "Florence Scott Libbey, about 1933" (143). These poems, which can be defined as tributes to the creators of the artworks that inspired them, as well as to the generosity of the Toledo Museum of Art's founders, also voice the love of these creators and founders for art and for what they have chosen to represent in their artworks. Throughout these tributes, via references and quotes to artists he admires (poets, writers, musicians...), he recreates an enlarged "Poet's Corner" where he can interact with artists and works of art and where he invites the reader to pray with him:

And together we will pray at the tomb of Donne

And then also share a silent pew in Poet's Corner

And at Poet's Corner we will say aloud Psalm 23

"The Lord is our shepherd; we shall not want" (67)

He transforms the "I" of Psalm 23 into a "we" to better indicate his wish to share this experience with the reader, his wish for the reader to partake in it. This book is not only his reconstructed version of the Toledo Museum of Art. It is the space through which he celebrates, commemorates, and shares his passion for artists and all the different forms 
of art they create. It is the space where an "Epiphany" (31) can be the result of an artistic device, just as the one he experienced while watching the "Cloister's Stellar Manipulator" "pressed a switch and [changed] the ceiling above the cloister [...] into a night sky" (33). The words "dream" and "cathedral" are repeated throughout WWE. In this book the poet "profanes" the museum by abolishing frontiers and separations and by playing with frames. He also recreates this museum, rebuilding it as an un-perverted new "Temple" where viewers and readers can truly enjoy art (to use Giorgio Agamben's concept of the museum and the meaning of profanation) ${ }^{17}$ : WWE is his cathedral within which he expresses his faith in art and encourages others to share his extended definition of "religion", to enjoy and to smile:

"Veronique, what are you into with religion?"

And I said: "Genetics" and he loved that

And I said "And you, Frankie,

Along with religion and sainthood what are you into?

"Painting Paintings" he rejoined

And he laughed again his mad saint's smile (WWE, 180-181)

\section{BIBLIOGRAPHY}

Agamben, Giorgio. Profanations. Trans. Martin Rueff. Paris : Rivages \& Payot, 2005.

Derrida, Jacques. La Vérité en peinture. Paris : Flammarion, 1978.

Dippie, Brian W. “Drawn to the West”. Western Historical Quarterly. 35.1 (Spring 2004): 4-26 (http:// www.jstor.org/stable/25442924)

Didi-Huberman, Georges. Devant le temps. Paris : Éditions de Minuit, 2000.

Durcan, Paul. Crazy About Women. Dublin: The National Gallery of Ireland, 1991.

Durcan, Paul. Give Me Your Hand. London: Macmillan, National Gallery Publications, 1994.

Durcan, Paul. O Westport in the Light of Asia Minor. London: The Harvill Press, 1975.

Durcan, Paul. Private interview, Dublin, 11 August 2011.

Durcan, Paul. Private email communication, 27 October 2016.

Durcan, Paul. The Days of Surprise. London: Harvill Secker, 2015.

Durcan, Paul. Wild, Wild Erie, Poems Inspired by Works of Art in the Toledo Museum of Art, Ohio. Toledo, Ohio: Toledo Museum of Art, 2016.

Hobsbawm, Eric. "The Myth of the Cowboy", extrait de Fractured Times, The Guardian, 20 March 2013: https://www.theguardian.com/books/2013/mar/20/myth-of-the-cowboy (last accessed July 23 2018).

Kennedy, Brian. “Crazy About Women: Poems About Paintings". The Kilfenora Teaboy, A Study of Paul Durcan. Colm Tóibín (ed.). Dublin: New Island Books, 1996.

Longley, Edna. "Introduction". The Selected Paul Durcan. Saskatoon and Belfast: Thistledown Press and the Blackstaff Press, 1982, 1989. xi-xv. 
McCracken, Kathleen. "Canvas and Camera Translated: Paul Durcan and the Visual Arts", The Irish Review. 7 (Fall 1989): 18-29.

McDonagh, John. The Art of the Caveman, The Poetry of Paul Durcan. Newcastle upon Tyne: Cambridge Scholars, 2016.

Murphy, William M. Prodigal Father, The Life of John Butler Yeats (1839-1922). Ithaca and London: Cornell UP, 1978.

Pater, Walter. “The School of Giorgione”. The Renaissance: Studies in Art and Poetry (1893). Ed. Adam Phillips. Oxford: OUP, “The World's Classics”, 1986. 83-98.

Roche-Liger, Cathy. "Punctuation Marks and Points of Detail in Paul Durcan's Intermedial Poetry". Point, Dot, Period ... The Dynamics of Punctuation in Text and Image. Laurence Petit, Laurence and Pascale Tollance (ed.). Newcastle upon Tyne: Cambridge Scholars, 2016, 68-83.

Reich, Paula. Toledo Museum of At Map \& Guide, second edition. London: Scala Publishers Ltd in association with the Toledo Museum of Art, 2009.

Wordsworth, William. Selections from William Wordsworth. Poetry and Prose. London: Methuen \& co Ltd, 1966.

The Toledo Museum of Art website (www.toledomuseum.org) and the page on Mauve's work http://www.toledomuseum.org/2014/01/17/artwork-of-the-week-january-17/ (last accessed July 23 2018).

\section{NOTES}

1. $C A W$ is composed of forty-seven poems and forty-nine visual fine art pieces: oils (for the majority of the selection), temperas, watercolours and sculptures. GMYH comprises forty-nine poems and fifty works of art which include mainly paintings but also a mural and two mosaics. In WWE, the diversity of the art objects selected is greater and again includes mainly paintings (especially oils), but also etchings, lithographs, photographs, a decorative box, a cast, sculptures, and architectural elements with the cloister gallery and its mediaeval arcades.

2. Durcan declared that he would like to be able to achieve what was for Wordsworth at the source of poetry itself: "emotion recollected in tranquillity" (Durcan, private interview; Wordsworth 199).

3. The pronoun "I" can also refer to someone observing a painting's characters (as in "The Flight Into Egypt, about 1540-45", 19-21), or to Durcan superimposed on a painting's character (as in "Another Chance, 1944", 151, a whimsical self-portrait intertwined with the painting's ekphrasis).

4. Durcan confirmed Kitaj was "much on [his] mind-he [Kitaj] being from Ohio" when the poet wrote his 2016 collection (Private email communication). In WWE, Durcan also pays a more direct tribute to Kitaj in his ekphraseis "Notes Toward a Definition of Nobody-a Reverie" and "The Hammock" (159-162, 196).

5. "[...] the 'western' in its modern sense-that is, the myth of the cowboy-is a late variant of a very early and deep-rooted image: that of the wild west in general. [...] The original image of the wild west, I suggest, contains two elements: the confrontation of nature and civilisation, and of freedom with social constraint. [...] many white protagonists of the original wild west epic are in some sense misfits in, or refugees from, 'civilisation', but that is not, I think, the main essence of their situation. Basically they are of two types: explorers or visitors seeking something that cannot be found elsewhere [...]; and men who have established a symbiosis with nature, as it exists in its human and non-human shape, in these wilds. In terms of literary pedigree, [...] the 
invented tradition of the west is entirely symbolic, inasmuch as it generalises the experience of a comparative handful of marginal people."

6. "The sweetest apple is soonest rotten / The hottest love is the soonest cold / What cannot be cured love must be endured love / And now I am bound for America"

7. The repetition with variation of the reference to the Dutch Road echoes the title and creates a sort of imperfect framing effect which heightens the pictorial dimension of the poem.

8. My translation ("image dialectique", 117; "la paradoxale fécondité de l'anachronisme", 20). For Georges Didi-Huberman: "The present moment of the emergence [of the dialectical image] gives rise to the fundamental nature of the possible connection between Now (moment, lightning) and Then (latency, fossil), a connection of which the Future (tension, desire) will bear some signs" ("Le présent [...] [du] surgissement [de l'image dialectique] donne la forme fondamentale du rapport possible entre le Maintenant (instant, éclair) et l'Autrefois (latence, fossile), rapport dont le Futur (tension, désir) gardera des traces"), 117).

9. 34 occurrences in the first stanza.

10. See for instance "Il Bambino Dormiente" (26-28).

11. Pater wrote in "The School of Giorgione" that "[a]ll art constantly aspires towards the condition of music" (86).

12. He whimsically magnifies himself by associating himself with them, underlining that the three of them (Durcan, Wilde and Collins) were born on 16 October.

13. The poet's main residence is in Dublin but he also spends a part of the year in Westport.

14. This phrase also echoes and contrasts with the line "Night in the forest can be a light into paradise" (103).

15. Cf. Kennedy's Foreword in WWE (11) where he refers to Durcan's "erudition and power of research".

16. "Under the Snow-White Palace of the Autumn Moon" (42); "Mirror, mirror on the wall, / Who is the fairest one of all" (184).

17. "Le Musée occupe exactement l'espace et la fonction qui étaient autrefois réservés au Temple comme lieu du sacrifice. Aux fidèles dans le Temple (ou aux pèlerins qui sillonnaient la terre de temple en temple, de sanctuaire en sanctuaire) correspondent aujourd'hui les touristes, qui voyagent sans paix dans un monde dénaturé en Musée"; "profaner ne signifie pas seulement abolir et effacer les séparations, mais apprendre à en faire un nouvel usage, à jouer avec elles » $(110-111,115)$.

\section{ABSTRACTS}

Wild, Wild Erie is the third book by the contemporary Irish poet Paul Durcan, the poems of which are inspired by a museum collection (namely here the Toledo Museum of Art, Ohio). In this collection, the poet deconstructs and reconstructs the museum space and the American Wild West myth. He adopts the stance of a new type of cowboy, one who is able to blur or transcend geographical, temporal or generic frontiers through ekphrasis. The poet wants to extend, transform or bring down limits and forms of categorization. He explores new space, bringing the reader along with him on a new journey. He also plays with frames and labels. Throughout the book, everything is in a state of perpetual transformation and the poet simultaneously or successively appears as an explorer, a "gallery-tripper", an "art-nerd", a scholar/a "Volunteer 
Teacher and Guide", an enchanter/"Stellar Manipulator". He de-frames the works of art before reproducing them on the open free space of a large, wide margin where one can dream freely. Nonetheless, each of these poems can be conceived as a new frame, as a new parergon (to use Derrida's concept), both a part of the artwork and exterior to it, both extending it and delineating it. Durcan lists, identifies and categorises the works, as in a museum catalogue. He influences and slants the reader's way of looking at the works of art. Wild, Wild Erie is a new, alternative museum guide, an invitation to true enjoyment of museums and a rejection of mere tourist consumerism of art. Ekphrasis becomes a new form of "intercourse", a real exchange between words and image leading to intense pleasure. Through poems and images, Paul Durcan builds a new temple, a cathedral where he reasserts his faith in art and invites the reader to come and pray, smile, imagine, or love.

Wild, Wild Erie est le troisième recueil du poète irlandais contemporain Paul Durcan. Il se compose de poèmes ekphrastiques inspirés par la collection d'un musée (en l'occurrence, le Toledo Museum of Art, Ohio). Dans ce recueil, le poète déconstruit et reconstruit l'espace muséal et le mythe de l'Ouest sauvage américain. Il se présente comme un nouveau cowboy qui, par le biais d' ekphraseis, vient brouiller voire transcender la notion de frontières, que celles-ci soient génériques, géographiques ou temporelles. Or le poète ne tente pas seulement de dépasser la notion de limites, d'explorer de nouveaux chemins et d'y entraîner le lecteur, il joue aussi avec les cadres, les étiquettes et les dénominations. Il crée un espace où rien n'est fixe, où tout est en constante évolution, espace à travers lequel le poète peut être perçu à la fois et tour à tour comme visiteur/explorateur, amateur d'art, érudit, «professeur», "guide » ou enchanteur/ «allumeur d'étoiles». Il dé-cadre les œuvres picturales et sculpturales avant de les reproduire sur l'espace de la page blanche, ne mettant aucune barrière entre l'œuvre et la marge, espace ouvert à la rêverie. Cependant, chacun de ces poèmes peut être conçu comme une nouvelle sorte de cadre, comme un parergon, pour reprendre le terme de Derrida, extérieur aux œuvres tout en en faisant partie, les prolongeant et les délimitant. Durcan classe les œuvres, comme dans un catalogue de musée. Il oriente et recadre le regard du lecteur. Le recueil devient une sorte de guide de musée alternatif, une invitation à la jouissance et un rejet d'une forme de consommation touristique de l'art et du musée. L'ekphrasis établit un nouveau type de relations entre mots et images, une nouvelle forme d'échange qui mène à la jouissance. Paul Durcan construit par le biais de poèmes et d'images un nouveau temple, une cathédrale où il réaffirme sa foi en l'art et invite le lecteur à venir prier, sourire, imaginer, aimer.

\section{INDEX}

Keywords: anachronism, detail, ekphrasis, faith, frame, frontier, museum, myth, rapture, reconstruction, West

Mots-clés: anachronisme, cadre, détail, ekphrasis, foi, frontière, jouissance, musée, mythe, Ouest, réécriture, reconstruction

\section{AUTHORS}

\section{CATHY ROCHE-LIGER}

Cathy Roche-Liger wrote the first French thesis on the Irish poet Paul Durcan in 2011, focusing on his pictorial poetics. She has published several articles about Paul Durcan, and other contemporary Irish poets such as Michael Longley, John Montague, Harry Clifton, Trevor Joyce or Geoffrey Squires. She is particularly interested both in poetry and in the interactions between 
the visual and the verbal. She is a member of the FoReLL B1 research group, University of Poitiers (France), which specializes in "Forms and Representations in Literature". 